\title{
Sustainable Agriculture in the Arabian/Persian Gulf Region Utilizing Marginal Water Resources: Making the Best of a Bad Situation
}

\author{
J. Jed Brown, Probir Das and Mohammad Al-Saidi * \\ Center for Sustainable Development, College of Arts and Sciences, Qatar University, P.O. Box 2713, Doha 2713, \\ Qatar; jedb00@gmail.com (J.J.B.); probir.das@qu.edu.qa (P.D.) \\ * Correspondence: malsaidi@qu.edu.qa
}

Received: 12 March 2018; Accepted: 24 April 2018; Published: 27 April 2018

\begin{abstract}
One way to encourage agricultural self-sufficiency in arid regions is to increase the productivity of conventional freshwater agriculture. Another way is to develop and implement novel strategies and technologies that do not deplete scarce freshwater. Here we describe several options for countries in the Gulf region to increase their agricultural production by taking advantage of a lesser used resource-marginal water. Marginal water can be treated sewage effluent, produced oilfield water, brackish groundwater or seawater. We describe how this resource can be used to grow salt-tolerant forage crops, microalgae and aquaculture crops. Policies needed to implement and/or scale-up such practices are also outlined.
\end{abstract}

Keywords: Arabian Gulf; Persian Gulf; GCC; microalgae; saline agriculture; halophytes; aquaculture; treated sewage effluent; produced water; aquafeeds

\section{Introduction}

As a result of the arid/hyper-arid climatic conditions, the majority of the area of the Gulf Cooperation Council Countries (GCC-Bahrain, Kuwait, Oman, Qatar, Saudi Arabia and UAE) is beset by a lack of freshwater resources. This lack of freshwater is an obvious constraint to development of conventional agriculture in this region. Arable land is quite limited, averaging around $4.25 \%$ of the total land area in the GCC region [1]. At the same time, water use for irrigation and livestock represent the biggest share of total water use, $45 \%$ in Bahrain, $54 \%$ in Kuwait, $88 \%$ in Saudi Arabia, $89 \%$ in Oman, $59 \%$ in Qatar and $83 \%$ in the UAE (FAO Aquastat for the year 2014). Local agriculture largely depends on the use of non-renewable groundwater supplies and suffers from poor practices such as low irrigation efficiency, leakages due to poor agricultural water networks and water-intensive cropping patterns [2]. Altogether, freshwater resources in the region are becoming threatened by agricultural water overuse and mismanagement. There are, however, opportunities for food production and/or landscape that do not entail the utilization of large quantities of freshwater.

One way forward would be to concentrate on conducting conventional agriculture more sustainably. There have been many attempts in the region to improve local agricultural production through the development of soil surveys and measures to improve productivity [3]. However, in reality, since the rate of groundwater recharge is so slow in this region, one could argue that any use of this fossil groundwater resource is not sustainable, as this is essentially a non-renewable resource. Similarly, use of desalinized water for agriculture will not be sustainable due to the high energy costs associated with the desalination process in the GCC region, namely between $\$ 0.45$ (subsidized) and $\$ 1$ per cubic meter [4]. 
Therefore, food imports are expected to increase in the region in order to meet the region's growing population. Sustainable local agriculture of some type needs to be developed or enhanced in order to provide some level of self-sufficiency using crops suitable for the desert climate [5].

Another way forward would be to try to make use of marginal or underutilized water sources. For example, the region does have access to seawater in the Arabian (Persian) Gulf. Additionally, there is also a large volume of brackish water that is too saline for conventional agriculture, which underlies much of the region. This brackish water is present naturally, and/or has increased due to the increased freshwater abstraction followed by seawater intrusion. For example, in Qatar in 2009, only $2 \%$ of the land area was underlain by high quality freshwater that is less than 1 part per thousand (ppt) salt and only $8 \%$ of the land was underlain by water less than 2 ppt salt [6]. In other words, over $90 \%$ of the land area is underlain by groundwater that is far too saline for any type of conventional agriculture; therefore, there is huge unutilized resource in Qatar and other Gulf countries that could be used for non-traditional agriculture.

Additionally, large quantities of treated sewage effluent are underutilized. And finally, there are large volumes of produced water available in the Gulf, that is, water that is produced in the process of oil and gas extraction, which could be used for agriculture. The potential to use such marginal water sources for food and landscape production will be explored here. In particular, we explore the use of marginal water to produce salt-tolerant plants (halophytes), micro-algae and mariculture products. To meet the food demand of the world's growing population, it is critical to develop novel agricultural systems that can take advantage of vast non-arable arid land areas and brackish water. Further, the challenges facing large-scale adoption of the highlighted alternatives for enhancing local agriculture will be discussed. Here we deem seawater as a marginal water source in the sense that it cannot be used for conventional agriculture, not meaning to imply that it is of poor quality.

\section{Treated Sewage Effluent (TSE)}

The use of treated domesticated wastewater or treated sewage effluent (TSE) for irrigating agricultural crops and landscapes is a widely used method to conserve and re-use water. TSE is widely used for these purposes in Gulf countries and other arid countries [7]. However, this TSE resource is underutilized. Currently, the wastewater treatment average in the GCC is around 56\%, while only $43 \%$ of the treated wastewater in the region is being recycled, contributing to only $1.8 \%$ of total water supply [8]. One of the chief reasons for this wastage is due to poorly organized or fragmented distribution networks, which makes dispersal of this resource difficult or problematic. In Qatar, currently, a large percentage of the TSE that is utilized for agriculture is used to grow forage grasses (mostly Rhodes grass) to feed livestock (M. Atta, Qatar Ministry of Environment, personal communication). However, much of this grass-growing takes place adjacent to the sewage treatment plants. This is fine if your farming land is next to the sewage treatment plant. However, if your farm is distant from the sewage plant, (e.g., northern Qatar), then it is obviously difficult to gain access to this water. Wastage of the TSE is not only an environmental sustainability issue but also an economic one. So from a longer term perspective, it makes sense to develop more integrated wastewater distribution networks. The State of Qatar plans to more than double the allocation of TSE to agriculture/fodder production by 2020 and estimates that this will result in a three-fold increase in domestic livestock herd size.

Similarly, TSE can be wasted if it used to irrigate plants that require a great deal of water or very frequent irrigation. Use of drought tolerant plants (xerophytes), particularly native species, for landscaping can further reduce the demand on TSE. Although TSE is certainly an option for agriculture, many concerns exist as to its safety and social acceptability, particularly the accumulation of heavy metals that are toxic to humans and animals, as well as the potential to transmit pathogenic micro-organisms [9-12]. TSE typically has higher salt (200-3000 mg/L TDS), nutrient, solids and frequently metal content than conventional irrigation water [13-16] and it has been observed that these metals can accumulate in food crops. For example, a recent study in which TSE was used to grow okra 
in Saudi Arabia found that the okra frequently accumulated $\mathrm{Ni}, \mathrm{Pb}, \mathrm{Cd}$ and $\mathrm{Cr}$ above safe limits and the authors concluded that the vegetable was not safe for direct consumption by human beings [17]. But other reviews have noted that high metal content in TSE is not a universal fact and can vary among localities [18].

Solids and nutrients such as nitrogen and phosphorus can improve the water holding capacity and the fertility of the soils, respectively [18], which can be particularly beneficial for arid land soils. The increased salt content of the TSE can increase salinity/sodicity of the soil especially in arid areas and this may or may not affect crop yields; basically higher salinity water will decrease yields [19], whereas lower salinity may not (e.g., [20]). Irrigation strategies such as using a high leaching fraction can be employed to decrease soil salinity and flush salts below the root zone [19]. In summary, TSE represents a useful water resource but systems need to be monitored to ensure that concentrations of heavy metals and salts are not becoming a problem.

\section{Produced Water}

Produced water, which is generated during the extraction of oil and gas from the ground, may also be a potential source for irrigation water, especially given the huge petroleum industry in the Gulf. Produced water is a combination of formation water that is trapped with oil and gas and the injection water that is used to enhance recovery rates of the oil and gas [21]. Produced water contains organic and inorganic chemicals where the salinity can range from close to freshwater to concentrated saline brine; aromatic hydrocarbons, some alkylphenols and a few metals from produced water are potential environmental concerns [21]. A wide variety of methods are available to treat produced water [22]. Currently most produced water in the Gulf is re-injected into the reservoir to maintain pressure, or injected into a disposal well.

Produced water from the Gulf tends to be saline—one study found $5 \mathrm{~g} / \mathrm{L}$ TDS in produced water from a Qatar gas field [23] and much higher in Kuwait $100 \mathrm{~g} / \mathrm{L}$ [24]. Produced water from oilfields has been used to irrigate crops in California for over 30 years [25]. Perhaps produced water could also be used in the Gulf for irrigation or algae cultivation. If salt-tolerant crops or algae are grown, then depending on its salinity, perhaps the produced water would only need to be treated to remove hydrocarbons and would not need to be desalinated, thereby reducing costs.

\section{Use of Saline Water for Terrestrial Agriculture}

Most conventional crops are sensitive to salt in the irrigation water and depending on the crop, yields will generally begin to decrease with irrigation water conductivities of 1-3 ds/m [26]. There are, however, salt-tolerant plants, called halophytes that can grow and complete their life cycles in saline water. Halophyte species have been identified to produce a variety of useful products, including firewood or timber from mangroves for example [27]; fresh vegetables [28,29]; oilseeds [30-32]; grains [31]; medicine [33,34]; forages for livestock [35-37]; for phytoremediation [38,39]; biofuel [40-43]; as biofilters for saline aquaculture effluent $[44,45]$ and ornamentals [46]. There have been efforts to grow some of these species in agricultural settings using seawater [30,31]. There are many halophyte species native to the Gulf that could be considered for potential crops for saline-water irrigation [47].

Perhaps the most promising use of halophytes in the GCC region might be for use as forage. Livestock, especially sheep, are widely grown for meat production in the Gulf. Large quantities of water are used to irrigate to grow these forages, such as Rhodes grass, for livestock. Many countries subsidize or recently ended subsidies for forage production. These subsidies led to increased use of fresh water for agricultural irrigation. For example, in the Emirate of Abu Dhabi, which ended subsidies to farmers for producing Rhodes grass in 2010, up to $59 \%$ of the total irrigation water volume was to grow Rhodes grass [48]. Not only is Rhodes grass subsidized but other feed ingredients such as wheat bran and barley are also subsidized. Developing locally-produced feed ingredients will not only increase food independence but will also be an incentive for the government to remove subsidies for feed ingredients and thereby reduce spending. 
Halophytes can comprise a portion of livestock feed and in particular, sheep feed. It has been observed that in circumstances where sheep have access to halophytes and other low quality forage supplements, the animals remained healthy and could gain weight [49]. Similarly, when sheep in pens were fed halophytes mixed with grain, animals had modest weight gains and produced high lean meat [49]. Meat from sheep fed halophyte-based diets has been found to have high eating quality [49] and the high vitamin E levels in the halophytes improved the shelf life of meat and can potentially benefit human health [50].

The potential forage plants fall into two categories. Firstly, the grasses, which tend to exclude salts from their tissues, grow at low-moderate salinity and under irrigation they have been reported to produce up to $40 \mathrm{t} \mathrm{DM} /$ year [51-55]. Biomass yields of about $60 \mathrm{t} / \mathrm{ha} /$ year (fresh weight) for Panicum antidotale were reported when grown in saline soil (EC $10-15 \mathrm{mS} \mathrm{cm}^{-1}$ ) and irrigated with brackish water (EC 10-12 $\mathrm{ms} \mathrm{cm}^{-1}$ ) [52]. The plant was subjected to analysis for both nutrient and anti-nutrient factors and cattle fed a P. antidotale diet achieved growth and meat production equivalent to those fed a conventional maize-based diet.

Other grasses have also been successfully used to replace ingredients such as maize forage in ruminant diets [56-58]. They produced similar biomass to conventional pasture plants and did not accumulate salt. However, the grasses tend to be low in nutritive value (metabolizable energy and crude protein), indicating that high quality supplements must also be added to ensure that the animals can grow quickly. Variation in nutritive value between plant species allows for the potential to select plants that can support higher levels of livestock production [59].

The second category are dicot plants that grow well under highly saline conditions, such as seawater. The dicot halophytes accumulate salt in their tissues, are succulent and tend to have high nitrogen content. These plants often have low biomass production when grown under extensive arid conditions [60] but this has been reported to increase to $20 \mathrm{t} \mathrm{DM} /$ ha under seawater irrigation for the oilseed halophyte Salicornia bigelovii [31]. Ruminants are moderately tolerant of salt and can grow well with a salt intake of up to $5 \%$ of the diet [61]. The high nitrogen levels in halophytes may be beneficial as ruminants fed adequate energy can convert plant nitrogen into protein. Therefore, these dicots can be included as a significant component of a total mixed ration to provide energy and a nitrogen source for protein production. It has recently been shown that halophytes can be included as a significant component of a feedlot diet in a series of experiments investigating how consumption of halophytes influences meat eating quality $[49,50,62,63]$. Sheep that were fed diets that contained a high proportion of halophytes exhibited moderate weight gain and produced meat with a high eating quality (determined by a taste panel) and the meat also had extended shelf life. Similar to the grasses, there is variation in nutritive value across these plants and their value as a feed component can be improved through management and selection $[64,65]$.

\section{Marginal Water to Cultivate Microalgae for Use as Feed}

Although the production of algae for biofuel may not be economically feasible currently, there may be some value to grow algae for its protein content to be used as component of aquafeeds for aquaculture. Fish constitute a major source of animal protein in human diets. In addition to protein, fish also provide various polyunsaturated fatty acids (PUFA) which are very useful for human health. Capturing fish from the wild may not be sustainable in certain fisheries due to over-fishing. To meet the deficit in supply, fish farming is being developed in almost all parts of the world. The existing practice of farming fish, livestock and poultry mostly rely on terrestrial plants crops for the formulation of the feed; most of these plants require both arable land and freshwater. Therefore, expansion of fish farming will likely result in an increase in terrestrial feed production. The increase in feed production, would likely require energy and water-intensive irrigation systems. Furthermore, limited land and freshwater availability and widespread pollution are already creating pressure on the existing agricultural systems. 
Microalgae and cyanobacteria (hereafter collectively referred to as microalgae) are photosynthetic microorganisms which are found virtually world-wide. Some species can double their biomass multiple times in a single day, under favorable growth conditions. The potential biomass production of selected microalgae strains can be an order magnitude higher than any other terrestrial plants (Table 1).

Table 1. Comparison of aerial biomass productivity of conventional feed sources with a few marine microalgae with commercial potential.

\begin{tabular}{ccc}
\hline Feedstock & Yield (t/hectare) & Reference \\
\hline Corn & 9.4 & {$[66]$} \\
Soybean & 2.7 & {$[67]$} \\
Wheat & 5.7 & {$[68]$} \\
Nannochloropsis sp. $\phi$ & 80.3 & {$[69]$} \\
Nitzschia sp. $\phi$ & 78.8 & {$[70]$} \\
Isochrysis galbana $\phi$ & 86.1 & {$[71]$} \\
Phaeodactylum tricornutm $\phi$ & 63.7 & {$[72]$} \\
\hline \multicolumn{2}{c}{$\phi$}
\end{tabular}

While seawater and saline groundwater are ideal water sources to grow microalgae, TSE could be another source of water for growing microalgae biomass. TSE could also be used as a makeup water to balance the daily evaporation loss. The availability of organic and inorganic compounds in the TSE could be beneficial for microalgal growth; however, certain toxic compounds and heavy metals, if present in high concentrations, could be absorbed into the microalgae biomass $[73,74]$. To eliminate or minimize the pathogens and other micro-organisms in the microalgae culture, a disinfection method should be applied to the TSE; some of the advanced wastewater treatment plants s are applying chlorination before reusing the TSE. In case, if the concentration of heavy metals in the TSE is high, the TSE could be diluted with seawater or the brackish water [75].

Microalgae are composed of carbohydrate, protein, and lipids, as well as other secondary metabolites (e.g., pigments, vitamins, and minerals). The concentration of these metabolites can vary among strains and growth conditions. Protein content in certain microalgae and especially in cyanobacteria can exceed $50 \%$ of the dry weight (see Table 2). Furthermore, some of these strains have all the essential amino acids in the desired ratio, unlike conventional protein sources (e.g., cornmeal, wheat gluten meal and soy meal.) for proper protein synthesis (see Table 3). A few of the strains can produce copious amount of omega-3 polyunsaturated fatty acid (e.g., EPA and DHA) which terrestrial plants cannot synthesize. These fatty acids are beneficial for human health. Human dietary intake of these fatty acids is mainly derived from consuming wild and farmed fishes. However, the primary source of these fatty acids are the aquatic photosynthetic microbes. It was further reported that as per their nutritional value and digestibility, algae were on par or even exceeded many other sources of feed [76]. Taking advantage of their prolific growth rate and high protein content, researchers explored the commercial exploitation of these strains as single cell proteins beginning in 1960 [77]. However, large-scale deployment of this technology was not practiced because of higher production costs at that time and the algae odor (fish-like) proved problematic for direct human consumption. With the dwindling supply and increased price of fishmeal in recent times [78], it is becoming crucial to develop cost and energy effective techniques for microalgal biomass production. 
Table 2. Metabolites composition of some of the microalgae and cyanobacteria.

\begin{tabular}{ccccc}
\hline Strains Name & Protein (\%) & Carbohydrate (\%) & Lipid (\%) & Ref. \\
\hline Chaetoceros sp. & 33 & 12 & 20.9 & {$[79]$} \\
Dunaliella sp. & 25.7 & 40.2 & 18 & {$[80]$} \\
Isochrysis sp. & 47.9 & 26.8 & 14.5 & {$[81]$} \\
Nannochloropsis sp. & 30.3 & 9.6 & 21.8 & {$[82]$} \\
Phaeodactylum sp. & 49.5 & 45.5 & 5.5 & {$[83]$} \\
Synechococcus sp. & 63 & 15 & 11 & {$[84]$} \\
Tetraselmis sp. & 30.7 & 33.6 & 17.6 & {$[85]$} \\
Chroococcidiopsis sp. & 60.3 & 22.2 & 3.8 & {$[86]$} \\
\hline
\end{tabular}

Table 3. The composition of essential amino acids ( $\mathrm{g} / 100 \mathrm{~g}$ protein) in different feed ingredients and microalga Nannochloropsis sp. and cyanobacterium Chroococcidiopsis sp.

\begin{tabular}{cccccc}
\hline EAA & $\begin{array}{c}\text { Fish Meal } \\
\text { (Herring) }\end{array}$ & Soybean Meal & Corn Meal & Nannochloropsis sp. & Chroococcidiopsis sp. \\
\hline Histidine & 2.4 & 1.442 & 0.91 & 1.5 & 0.8 \\
Isoleucine & 4.5 & 3.17 & 2.37 & 3.5 & 2.6 \\
Leucine & 7.5 & 5.53 & 10.26 & 6.7 & 7 \\
Lysine & 7.7 & 3.84 & 0.91 & 4.8 & 3.8 \\
Methionine & 2.9 & 0.81 & 1.09 & 1.8 & 0.4 \\
Phenylalanine & 3.9 & 2.76 & 2.79 & 3.9 & 6.3 \\
Threonine & 4.3 & 3.03 & 2.06 & 3.6 & - \\
Tryptophan & 1.2 & 0.57 & 1.3 & 1.7 & 7.8 \\
Valine & 5.4 & 5.59 & 2.85 & 4.6 & {$[86]$} \\
Reference & {$[87]$} & {$[88]$} & {$[89]$} & {$[90]$} & \\
\hline
\end{tabular}

\section{Challenges in Large-Scale Cultivation of Microalgae}

Current annual global production of microalgae biomass was estimated as 15,000 t [91]; every year, almost $1000 \mathrm{t}$ of produced biomass is being used to grow mollusks, shrimp and other fishes [92]. Live microalgae feed is preferable for certain types of fishes and aquatic invertebrates. Whole microalgae biomass or even metabolites extracted from microalgal are being successfully studied as feed ingredients for fish, cattle, and poultry. The major challenge in the production of large-scale microalgal biomass as feed is the production cost. Microalgae can be grown in photobioreactors (PBR) or open raceway ponds (ORP). Although PBRs have more control in the cultivation of the strains, preventing contamination and evaporative water loss, construction, operation and maintenance of the PBRs can be very energy and cost intensive [91], especially for bulk feed. On the other hand, biological contamination, evaporative water loss, relatively lower biomass density are some of the major challenges for operating ORPs. Fast growing and halophilic microalgae are ideal ORP candidates to minimize the effect of contamination and evaporation. For a few strains, the growth conditions are so extreme (low $\mathrm{pH}$, high $\mathrm{pH}$, hypersaline) that other strains cannot contaminate them in large-scale operations. In order to grow other useful strains, appropriate growth conditions should be developed that can prevent or minimize contamination from unwanted microalgae and predators.

Only a few microalgal strains have been extensively characterized for their nutritional properties; however, these strains might require very specific climate conditions. Therefore, more strains need to be isolated and characterized, especially from the area where microalgal cultivation would take place. For example, the very high light intensity and extreme temperature in the GCC region require strains which can flourish in such environments. Researchers have studied the biomass and lipid productivities of Nannochloris sp., Picochlorum sp., Desmochloris sp., isolated from Red sea, as feedstock for biofuel [93]. Similarly, in Kuwait, there were a few small-scale indoor studies of Nannochloropsis sp. and Chlorella sp. [94,95]. Several Dunaliella species can grow in hypersaline water (as high as $25 \%$ salt content) and produce $2-10 \%$ of the cell weight as $\beta$-carotene; several groups in the region explored the potential of growing Dunaliella strains [96,97]. Although there 
are multiple groups and companies conducting research on microalgae in the GCC region, only a few groups have demonstrated large-scale outdoor cultivation of selected strains. In Abu Dhabi, a larger, commercial-scale operation was initiated on a coastal island [96] but it has since ceased operating (Brown, personal observation). The Algal Technology Program (ATP) of Qatar University has a small-scale (1 hectare in size) research demonstration farm. ATP has isolated and preserved over 200 strains and microalgae and cyanobacteria from the surrounding environment [98]. Eleven marine cyanobacterial strains from the ATP strain bank were analyzed for paralytic shellfish toxins, microcystins, nodularins, anatoxins and cylindrospermopsins; none of the cyanobacteria had any of these toxins (data not published). On the contrary, some of these strains (Synechococcus sp., Leptolyngbya sp., Chroococcidiopsis sp.) produce high-value pigments like phycobiliproteins and carotenes that could improve feed quality. Some of the promising strains (e.g., Nannochloropsis sp., Tetraselmis sp., Chroococcidiopsis sp., Synechococcus sp., Chlorella sp., Scenedesmus sp.) were successfully grown in the desert at a scale $200 \mathrm{~L}-100,000 \mathrm{~L}[85,86,99,100]$.

Typical depth of microalgae culture in ORP's can be in the range of $20-30 \mathrm{~cm}$; the daily evaporative water loss can be $0.1-2.0 \mathrm{~cm}$, depending on the climate condition. To maintain the culture volume and water salinity, addition of freshwater was practiced for outdoor cultivation of most of the marine microalgae-however, TSE or other brackish water can be added to ensure sustainability in freshwater-scarce regions. Some potential halophilic microalgae (e.g., Tetraselmis sp., Dunaliella sp.) have the ability to adapt to incremental salinity in culture and therefore the evaporative water loss can be balanced by adding seawater $[85,101,102]$. Coastal areas are an ideal place for the cultivation of microalgae as the collection and pumping of seawater would require minimal energy. In the case of using brackish groundwater, the cultivation site should be selected such that the elevation difference between the water source and the ORP is minimized.

About half of the microalgae biomass is comprised of carbon and it was estimated that $1.73 \mathrm{~kg}$ of carbon dioxide is required to produce $1 \mathrm{~kg}$ of biomass [103]. The solubility of atmospheric $\mathrm{CO}_{2}$ in water is very low, which is inefficient to produce sufficient dense culture. Hence, an adequate amount of $\mathrm{CO}_{2}$ must be supplied to the culture; the rate of $\mathrm{CO}_{2}$ supply should match the growth rate of the biomass. $\mathrm{CO}_{2}$ uptake rate will vary among microalgae strains; however, to reduce the cost of $\mathrm{CO}_{2}$ utilization, efficiency should be increased. Although purified bottled $\mathrm{CO}_{2}$ is commonly used in research and commercial microalgae production, to reduce the production cost, flue gas from the power plants could be utilized. Therefore, large-scale microalgal cultivation sites could be co-located with a power plant or any other industry that generates an adequate amount of flue gas. In addition to carbon, nitrogen needs to be supplied in a useful form. Urea and other ammonium salts are commonly used as sources of nitrogen fertilizer. However, the waste from livestock, poultry and fishery processing industries can be processed and recycled as sources of nitrogen.

The cell size $(2-20 \mu \mathrm{m})$ and dilute concentration of microalgae in the culture $(0.5 \mathrm{~g} / \mathrm{L})$, makes biomass harvesting an energy-intensive process, which could contribute to as much as $40 \%$ of the biomass production costs. Sedimentation, filtration, and centrifugation are some of the conventional microalgal harvesting techniques. Coagulation-flocculation could also be used to harvest some microalgae. Bio-based coagulants (e.g., chitosan, poly $\gamma$-glutamic acid and rice starch) have been found effective in harvesting freshwater microalgae [104-106]. Since the marine microalgae cultures usually have much higher ionic strength compared to that of freshwater cultures, these organic coagulants are often less effective for harvesting marine microalgae; polyvalent metal coagulants (e.g., alum, ferric chloride) are often used to harvest marine microalgae. Presence of higher concentration of metals in the harvested biomass is not desirable [107,108]; very recently, it was shown that dilute acidic water could be used to recover the iron from the ferric-chloride coagulated harvested Chlorella sp. biomass [100]. There were a few attempts to bioflocculate the desired microalgae with other microalgae [109] and yeast [110] in small-scale studies; despite the efficient harvesting, this method requires a large amount of bioflocculating microorganisms that could affect the harvested biomass quality. Whereas the sedimentation process requires less energy, the centrifugation process consumes the most energy. 
However, only a few large cell size and colony forming microalgae undergo gravity sedimentation [86]. Microalgae are efficient in terms of nutrient utilization. However, after removal of the biomass, the harvested water often contains residual nutrients, which need to be recycled to improve the process economics and to prevent pollution. Usually, for large-scale biomass harvesting, two different methods are combined. In the first set, the biomass is separated from the bulk of the water using an appropriate method-the solid content in the harvested biomass slurry can be in the range of $1-2 \%$. Next, the biomass slurry is further dewatered to $10-30 \%$ solid content by adopting different techniques, based on the final use. Since the biomass still has a great deal of water, it is important to preserve the biomass soon after the harvesting process. Spray drying, although very energy intensive, is commonly used to dry the biomass.

\section{Marine Aquaculture}

In addition to microalgae production, an obvious use of the seawater resource is to use it produce high value products such as finfish, shellfish or crustaceans such as shrimp. As many scientists have noted, overfishing of wild fish stocks is not sustainable and leads to ecological collapse (e.g., [111]). Marine aquaculture, if conducted in a sustainable fashion, offers a path for food production in the Gulf that can potentially ameliorate overfishing of wild stocks.

Given that revenues from petroleum resources are declining, combined with the reduced harvest of wild fish, many of the Gulf countries have invested or are planning to invest in aquaculture. Oman is currently considering investing in 24 aquaculture projects with a value of over 2 billion USD ([112]. Similarly, Saudi Arabia has developed many hectares of aquaculture ponds on its Red Sea coast and Qatar has requested tenders for companies to operate aquaculture facilities [113].

In addition to fish and shrimp, consideration could also be given to lower value species such as seaweeds (macroalgae). Seaweeds can be used for human food and also for industrial purposes such as for the production of hydrocolloids such as carrageenans, agar and alginates. Plus they have they the added value of being able to uptake large amounts of nutrients, thus, cleaning the water and reducing eutrophication [114].

There are many challenges for the aquaculture industry in the Gulf. Firstly, if there is a desire to develop local capacity and expertise (as opposed to using skilled expatriate labor), then there will be a need to develop specially trained technical staff, with specialized knowledge across many disciplines. It has been observed that a successful aquaculture team should have mechanical and electronic skills, a strong working knowledge of water chemistry, fish nutrition and health management and that one of the most critical components of establishing a successful aquaculture operation is building a team capable of managing across this wide range of disciplines [115]. Additionally, to increase sustainability, the industry should strive to develop local fish feeds that utilize local ingredients where practicable. Care should also to taken to avoid overcapitalization/overdevelopment of the sector. Diseases are always a challenge for aquaculture operations.

The high temperatures and salinity of the Gulf can make it challenging to grow many species-the growth rates of most species will suffer in the hot summer temperatures. Selecting and improving locally-adapted species to culture will likely be more prudent than importing and growing non-native species. Lastly, over time, as the Gulf gradually becomes hotter and more saline due to climate change and due to the increase in desalination operations, it may ultimately not be feasible to raise fish in the Gulf in the more distant future.

\section{Integrated Seawater Agriculture}

Another potential way forward is to combine or integrate the terrestrial high salinity agriculture with an aquaculture operation for fish or shrimp and even microalgae. In such a system, seawater (saline groundwater could also be used) can be pumped to ponds on land where fish and/shrimp can be grown. The wastewater which leaves the ponds, which is enriched in nutrients such as nitrogen and phosphorus, can be used to irrigate terrestrial halophytes. Water that then drains from the halophytes 
fields can then be polished by mangroves in a mangrove wetland or excess water could drain into a pond for microalgae production. Salinity of the water will increase as it moves through the system due to evaporation and transpiration from the plants. Typically, the halophytes will need to be irrigated in excess of their evapotranspiration requirements to provide a leaching fraction to leach salts below the plant root zone. A study of seawater irrigation of Salicornia bigelovii in a coastal desert found that the leaching fraction was 0.35 , or about $35 \%$ of the total seawater applied at the surface leached below the plant root zone. The salinity of the leachate water increased to over $100 \mathrm{~g} / \mathrm{L}$ by the end of the growing season, indicating that additional seawater or other water, e.g. TSE, might need to be added to the water draining from the halophytes if it was to be used subsequently for microalgae production or if it was to be recirculated.

The advantages of such a system is that the water only needs to be pumped once from the sea and the aquaculture wastewater is utilized as a fertilizer for the halophytes or microalgae. The aquaculture products would provide most of the income from such a farm and the halophyte biomass could be used as a biofuel feedstock. A recent study showed that for a theoretical integrated seawater agriculture system located in the Gulf, where the halophyte biomass was used to produce aviation biofuel, that such a system would generate 38 to $68 \%$ less greenhouse gases than conventional fossil jet fuel production and would yield an overall positive net energy balance [116].

Several such systems have been built, most notably in Eritrea and in Mexico. Although these systems may have functioned from a technical perspective, they were not successful business efforts. A comprehensive study of these efforts noted that these projects failed due to "political instability, mismanagement and community opposition" [117]. Developers of future projects in this area should therefore pay greater attention to the socio-economic aspects of such projects at the planning stages.

\section{Discussion of Challenges with Scaling up}

The willingness to accept the use of marginal water for food production on a wide scale depends on the maturity of technologies to deliver suitable, high quality crops. At the same time, the presented food production alternatives are at different levels of development and commercial readiness. The use of TSE for conventional crops is the most advanced and viable option in the short run. (Although mariculture is also an advanced food production technology in many regions, it can also entail significant economic investment and is frequently fraught with significant financial risk). The wastewater treatment rate in the GCC varies across countries from $41 \%$ in Oman to $75 \%$ in Kuwait, while the mean reuse rate does not exceed $30 \%$ due to fluctuations in water quality and the lack of distribution networks [8]. Expanding TSE reuse across the GCC is expected to increase and thus contribute to decreasing the reliance of groundwater use for agriculture. TSE can supply up to $10 \%$ of water demands in the region by the year 2020, if the current plans are realized and obstacles such as farmers' acceptance and adequate distribution networks are solved [118].

Similarly, using saline water for agriculture is an untapped resource that can help save vulnerable freshwater resources. This option is still not explored on a large scale in the region. Instead, the use of saline water for irrigation is sometimes seen as unsustainable as policymakers believe that it will salinize soils or aquifers. However, the suggestion here is to conduct saline agriculture only in areas with existing saline soils or aquifers, not in areas with high quality arable land. Nevertheless, the salinity of water and soil should be monitored in all areas to ensure productivity of agricultural lands in the future $[3,119]$. Therefore, for policymakers in the region, saline agriculture is yet to become accepted as a viable opportunity to produce animal feed or other crops.

As for microalgae, it might require special funds to move to advance its commercialization. Over the last few years, the cultivation of microalgae has been going through the transition from research and pilot-scale demonstration to full-scale commercial deployment. The fundamental aspects of large-scale microalgae cultivation are very similar to that of existing aquaculture and even agriculture. However, until now, microalgal cultivation neither falls under agriculture nor receives any benefits which are often given in agriculture. Consideration might be given to providing support to the microalgae 
industry from either government or the private sector for continued research and development and subsequent commercialization.

There are key socio-economic challenges that can hinder the use of marginal water on a wide scale. First, the awareness and the availability of agricultural services trained on alternative production systems are necessary to promote marginal water use. Second, setting the right water pricing policies is crucial to encourage the use of marginal water. In fact, the overconsumption of water and the overuse of non-renewable freshwater resources in the region is associated with the high subsidies for water and energy services. Water and energy production systems are highly interlinked in the GCC. High amounts of cheap energy are used to desalinate water, which is then provided at subsidized prices and in some countries free of charge for national residents and also used in agriculture [120,121] Although GCC countries have moved to gradually reduce subsidies, the lack of universal tariffs on water use and wastewater treatment is one of the key constrains to water reuse policies [8]. At the same time, energy subsidies account for over $8.5 \%$ of the GDP and $22 \%$ of public spending in the GCC region [122]. Reducing these subsidies can free up resources that can be invested in promoting alternative food production systems such as saline agriculture or the cultivation of microalgae.

Third, alternative production systems using marginal water need to be incorporated in clear national strategies for enhancing food and water security. Until now, the majority of options to reduce freshwater use in food production do not focus on marginal water. These options include improving irrigation technologies, increased land investments abroad, improving agricultural productivity, reducing food waste and exploring alternative food production systems such as vertical farming [123]. Moreover, desalinated water is used for irrigation in many GCC countries and this option might increase if renewable energies contribute to reducing the high energy costs associated with desalination [124].

Concerning national food strategies and policies, the majority of the GCC countries lack comprehensive food security strategies with high-level endorsement and commitment. In 2008, Qatar initiated a National Food Security Program (QNFSP), which established a master plan to diversify food imports, increase aquaculture and develop integrated systems at the farm level with water reuse schemes. Although this policy represents the most comprehensive set of soft (awareness, education, research) and hard (infrastructure and investments) measures, there is no evidence that its implementation was endorsed by all stakeholders and it is not clear whether it was put into action. In 2015, the UAE, in cooperation with the Food and Agriculture Organization (FAO) developed a National Policy for Food and Agriculture, which was endorsed in 2016 by the Climate Change and Environment Ministry. This policy foresees, among others, market-driven reforms and investments in marine aquaculture. Aquaculture is also being promoted in other GCC countries such as Saudi Arabia, which regards this sector as one of the most promising options for food production under the Saudi Vision 2030.

\section{Conclusions}

Here we show that marginal water sources such as TSE, produced water, saline ground water and seawater can be used to produce a variety of useful crops. Utilization of such marginal water sources can potentially spare scarce freshwater resources. There is a significant potential for utilizing such marginal water in the GCC region. This potential is currently not fully exploited despite important advancements in research on use requirements and sectors. Further research should focus on the economic feasibility of some of these technologies in the GCC. If the economics are favorable, then these technologies should be able to provide economic diversification in the GCC countries, which are trying to increase economic activity in the non-petroleum sectors. The adequate commercial scale of technologies using marginal water needs further research. Moreover, reforming the subsidization of freshwater, especially for agriculture uses, can encourage the utilization of marginal water. Additionally, these technologies could aid in increasing domestic food production, which is a stated strategic goal of many of the GCC nations. In fact, the GCC region is highly dependent on 
global food markets despite many GCC countries using more than the global average of water for domestic agriculture. Advanced marginal water technologies can help reduce both freshwater use for agriculture and the dependence on food imports. For this, they need to be integrated in national strategic plans for food security. Such plans can develop clear targets and use incentives and public investments in order to promote the use of such technologies based on the individual commercial readiness of each of the technologies.

Author Contributions: J.J.B., P.D. and M.A.-S. wrote the article and contributed equally.

Conflicts of Interest: The authors declare no conflict of interest.

\section{References}

1. Kotilaine, J.T. GCC Agriculture. Available online: https://www.gulfbase.com/ScheduleReports/GCC_ Agriculture_Sector_March2010.pdf (accessed on 17 April 2018).

2. Saif, O.; Mezher, T.; Arafat, H.A. Water security in the GCC countries: Challenges and opportunities. J. Environ. Stud. Sci. 2014, 4, 329-346. [CrossRef]

3. Shahid, S.A.; Ahmed, M. Changing face of agriculture in the Gulf Cooperation Council countries. In Environmental Cost and Face of Agriculture in the Gulf Cooperation Council Countries-Fostering Agriculture in the Context of Climate Change; Shahid, S.A., Ahmed, M., Eds.; Springer: Berlin, Germany, 2014; pp. 1-25.

4. Alnaser, W.E.; Alnaser, N.W. The status of renewable energy in the GCC countries. Renew. Sustain. Energy Rev. 2011, 15, 3074-3098. [CrossRef]

5. Pirani, S.I.; Arafat, H.A. Interplay of food security, agriculture and tourism within GCC countries. Glob. Food Secur. 2016, 9, 1-9. [CrossRef]

6. Schlumberger Water Services. Study and Developing the Natural and Artificial Recharge of Groundwater Aquifer in the State of Qatar; Qatar Ministry of Environment: Doha, Qatar, 2009.

7. Bank, T.W. Improving Wastewater Use in Agriculture: An Emerging Priority; The World Bank: Washington, DC, USA, 2010; p. 190.

8. Aleisa, E.; Al-Zubari, W. Wastewater reuse in the countries of the Gulf Cooperation Council (GCC): The lost opportunity. Environ. Monit. Assess. 2017, 189, 553. [CrossRef] [PubMed]

9. Darwish, M.; Abdulrahim, H.; Mabrouk, A.N.; Hassan, A.; Shomar, B. Reclaimed wastewater for agriculture irrigation in Qatar. Glob. J. Agric. Res. Rev. 2014, 31, 106-120.

10. Jasim, S.Y.; Saththasivam, J.; Loganathan, K.; Ogunbiyi, O.O.; Sarp, S. Reuse of Treated Sewage Effluent (TSE) in Qatar. J. Water Process Eng. 2016, 11, 174-182. [CrossRef]

11. Hong, P.-Y.; Al-Jassim, N.; Ansari, M.I.; Mackie, R.I. Environmental and Public Health Implications of Water Reuse: Antibiotics, Antibiotic Resistant Bacteria, and Antibiotic Resistance Genes. Antibiotics 2013, 2, 367-399. [CrossRef] [PubMed]

12. Ouda, O.K.M. Treated wastewater use in Saudi Arabia: Challenges and initiatives. Int. J. Water Resour. Dev. 2016, 32, 799-809. [CrossRef]

13. Elgallal, M.; Fletcher, L.; Evans, B. Assessment of potential risks associated with chemicals in wastewater used for irrigation in arid and semiarid zones: A review. Agric. Water Manag. 2016, 177, 419-431. [CrossRef]

14. Mohammad Rusan, M.J.; Hinnawi, S.; Rousan, L. Long term effect of wastewater irrigation of forage crops on soil and plant quality parameters. Desalination 2007, 215, 143-152. [CrossRef]

15. Da Fonseca, A.F.; Herpin, U.; de Paula, A.M.; Victória, R.L.; Melfi, A.J. Agricultural use of treated sewage effluents: Agronomic and environmental implications and perspectives for Brazil. Sci. Agricola 2007, 64, 194-209. [CrossRef]

16. Al Omron, A.M.; El-Maghraby, S.E.; Nadeem, M.E.A.; El-Eter, A.M.; Al-Mohani, H. Long term effect of irrigation with the treated sewage effluent on some soil properties of Al-Hassa Governorate, Saudi Arabia. J. Saudi Soc. Agric. Sci. 2012, 11, 15-18. [CrossRef]

17. Balkhair, K.S.; Ashraf, M.A. Field accumulation risks of heavy metals in soil and vegetable crop irrigated with sewage water in western region of Saudi Arabia. Saudi J. Biol. Sci. 2016, 23, S32-S44. [CrossRef] [PubMed] 
18. El-Zohri, M.; Hifney, A.; Ramadan, T.; Abdel-Basset, R. Use of Sewage in Agriculture and Related Activities. In Handbook of Plant and Crop Physiology, 3rd ed.; CRC Press: Boca Raton, FL, USA, 2014; pp. 931-966, ISBN 978-1-4665-5328-6.

19. Hussain, G.; Al-Saati, A.J. Wastewater quality and its reuse in agriculture in Saudi Arabia. Desalination 1999, 123, 241-251. [CrossRef]

20. Dorta-Santos, M.; Tejedor, M.; Jiménez, C.; Hernández-Moreno, J.M.; Díaz, F.J. “Using marginal quality water for an energy crop in arid regions: Effect of salinity and boron distribution patterns". Agric. Water Manag. 2016, 171, 142-152. [CrossRef]

21. Neff, J.; Lee, K.; DeBlois, E.M. Produced Water: Overview of Composition, Fates, and Effects. In Produced Water; Springer: New York, NY, US, 2011; pp. 3-54, ISBN 9781461400455.

22. Duraisamy, R.T.; Beni, A.H.; Henni, A. State of the Art Treatment of Produced Water. In Water Treatment; Elshorbagy, W., Chowdhury, R.K., Eds.; InTech: Rijeka, Croatia, 2013.

23. Janson, A.; Katebah, M.; Santos, A.; Minier-Matar, J.; Hussain, A.; Adham, S.; Judd, S. Assessing the biotreatability of produced water from a Qatari gas field. SPE J. 2015, 20, 1113-1119. [CrossRef]

24. Alfarhan, A.A.; Duane, M.J. Geochemistry and modification of oilfield brines in surface pits in Northern Kuwait. Arab. J. Geosci. 2012, 5, 1055-1068. [CrossRef]

25. Frequently Asked Question about Recycled Oilfield Water for Crop Irrigation. Available online: https:/ / www.waterboards.ca.gov/publications_forms/publications / factsheets/docs / prod_water_ for_crop_irrigation.pdf (accessed on 17 April 2018).

26. Shannon, M.C.; Grieve, C.M. Tolerance of vegetable crops to salinity. Sci. Hortic. 1998, 78, 5-38. [CrossRef]

27. Bandaranayake, W.M. Traditional and medicinal uses of mangroves. Mangroves Salt Marshes 1998, 2, $133-148$. [CrossRef]

28. Ventura, Y.; Sagi, M. Halophyte crop cultivation: The case for salicornia and sarcocornia. Environ. Exp. Bot. 2013, 92, 144-153. [CrossRef]

29. Ventura, Y.; Myrzabayeva, M.; Alikulov, Z.; Cohen, S.; Shemer, Z.; Sagi, M. The importance of iron supply during repetitive harvesting of Aster tripolium. Funct. Plant Biol. 2013, 40, 968-976. [CrossRef]

30. Glenn, E.P.; O’Leary, J.W.; Watson, M.C.; Thompson, T.L.; Kuehl, R.O. Salicornia bigelovii Torr.: An Oilseed Halophyte for Seawater Irrigation. Science 1991, 251, 1065-1067. [CrossRef] [PubMed]

31. Glenn, E.P.; Anday, T.; Chaturvedi, R.; Martinez-Garcia, R.; Pearlstein, S.; Soliz, D.; Nelson, S.G.; Felger, R.S. Three halophytes for saline-water agriculture: An oilseed, a forage and a grain crop. Environ. Exp. Bot. 2013, 92, 110-121. [CrossRef]

32. Weber, D.J.; Ansari, R.; Gul, B.; Ajmal Khan, M. Potential of halophytes as source of edible oil. J. Arid Environ. 2007, 68, 315-321. [CrossRef]

33. Xi, J.; Zhang, F.; Mao, D.; Yan, P. The utilization of halophytes for traditional medicine in Xin jiango Title. Rev. China Agric. Sci. Technol. 2003, 5, 43-48.

34. Qasim, M.; Gulzar, S.; Shinwari, Z.K.; Aziz, I.; Ajmal Khan, M. Traditional ethnobotanical uses of halophytes from Hub, Balochistan. Pak. J. Bot. 2010, 42, 1543-1551.

35. Swingle, R.S.; Glenn, E.P.; Squires, V. Growth performance of lambs fed mixed diets containing halophyte ingredients. Anim. Feed Sci. Technol. 1996, 63, 137-148. [CrossRef]

36. Masters, D.G.; Benes, S.E.; Norman, H.C. Biosaline agriculture for forage and livestock production. Agric. Ecosyst. Environ. 2007, 119, 234-248. [CrossRef]

37. El Shaer, H.M. Halophytes and salt-tolerant plants as potential forage for ruminants in the Near East region. Small Rumin. Res. 2010, 91, 3-12. [CrossRef]

38. Manousaki, E.; Kalogerakis, N. Halophytes present new opportunities in phytoremediation of heavy metals and saline soils. Ind. Eng. Chem. Res. 2011, 50, 656-660. [CrossRef]

39. Rabhi, M.; Ferchichi, S.; Jouini, J.; Hamrouni, M.H.; Koyro, H.W.; Ranieri, A.; Abdelly, C.; Smaoui, A. Phytodesalination of a salt-affected soil with the halophyte Sesuvium portulacastrum L. to arrange in advance the requirements for the successful growth of a glycophytic crop. Bioresour. Technol. 2010, 101, 6822-6828. [CrossRef] [PubMed]

40. Abideen, Z.; Ansari, R.; Khan, M.A. Halophytes: Potential source of ligno-cellulosic biomass for ethanol production. Biomass Bioenergy 2011, 35, 1818-1822. [CrossRef]

41. Moser, B.R.; Dien, B.S.; Seliskar, D.M.; Gallagher, J.L. Seashore mallow (Kosteletzkya pentacarpos) as a salt-tolerant feedstock for production of biodiesel and ethanol. Renew. Energy 2013, 50, 833-839. [CrossRef] 
42. Debez, A.; Belghith, I.; Friesen, J.; Montzka, C.; Elleuche, S. Facing the challenge of sustainable bioenergy production: Could halophytes be part of the solution? J. Biol. Eng. 2017, 11, 27. [CrossRef] [PubMed]

43. Bañuelos, J.A.; Velázquez-Hernández, I.; Guerra-Balcázar, M.; Arjona, N. Production, characterization and evaluation of the energetic capability of bioethanol from Salicornia Bigelovii as a renewable energy source. Renew. Energy 2018, 123, 125-134. [CrossRef]

44. Brown, J.J.; Glenn, E.P. Reuse of highly saline aquaculture effluent to irrigate a potential forage halophyte, Suaeda esteroa. Aquac. Eng. 1999, 20, 91-111. [CrossRef]

45. Shpigel, M.; Ben-Ezra, D.; Shauli, L.; Sagi, M.; Ventura, Y.; Samocha, T.; Lee, J.J. Constructed wetland with Salicornia as a biofilter for mariculture effluents. Aquaculture 2013, 412-413, 52-63. [CrossRef]

46. Ali, A.; Iqbal, N.; Ali, F.; Afzal, B. Alternanthera bettzickiana (Regel) G. Nicholson, a potential halophytic ornamental plant: Growth and physiological adaptations. Flora Morphol. Distrib. Funct. Ecol. Plants 2012, 207, 318-321. [CrossRef]

47. Cybulska, I.; Brudecki, G.; Alassali, A.; Thomsen, M.; Jed Brown, J. Phytochemical composition of some common coastal halophytes of the United Arab Emirates. Emir. J. Food Agric. 2014, 26, 1046-1056. [CrossRef]

48. Farms Stop Cultivating Rhodes Grass. Gulf News, 23 March 2012. Available online: https://gulfnews.com/ news/uae/environment/farms-stop-cultivating-rhodes-grass-1.998624 (accessed on 24 April 2018).

49. Pearce, K.L.; Norman, H.C.; Wilmot, M.; Rintoul, A.; Pethick, D.W.; Masters, D.G. The effect of grazing saltbush with a barley supplement on the carcass and eating quality of sheepmeat. Meat Sci. 2008, 79, 344-354. [CrossRef] [PubMed]

50. Pearce, K.L.; Masters, D.G.; Smith, G.M.; Jacob, R.H.; Pethick, D.W. Plasma and tissue $\alpha$-tocopherol concentrations and meat colour stability in sheep grazing saltbush (Atriplex spp.). Aust. J. Agric. Res. 2005, 56, 663-672. [CrossRef]

51. Pasternak, D.; Nerd, A.; De Malach, Y. Irrigation with brackish water under desert conditions IX. The salt tolerance of six forage crops. Agric. Water Manag. 1993, 24, 321-334. [CrossRef]

52. Khan, M.A.; Ansari, R.; Ali, H.; Gul, B.; Nielsen, B.L. Panicum turgidum, a potentially sustainable cattle feed alternative to maize for saline areas. Agric. Ecosyst. Environ. 2009, 129, 542-546. [CrossRef]

53. Al-Dakheel, A.; Al-Hadrami, G.; Al-Shorabi, S.; AbuRumman, G. Optimizing management practices for maximum production for two salt-tolerant grasses: Sporobolus virginicus and Distichlis spicata. In Proceedings of the 7th Annual UAE University Research Conference, Dubai, UAE, 22-24 April 2006.

54. Al-Dakheel, A.; Al-Hadrami, G.; Saleh Al-Shoraby, G.S.; Shabbir, G. The potential of salt-tolerant plants and marginal resources in developing an integrated forage-livestock production system. In Salinity, Water and Society-Global Issues, Local Action, Proceedings of the 2nd International Salinity Forum, Adelaide, Australia, 31 March-3 April 2008; Libraries Australia: Canberra, Australia, 2008; Volume 31, p. 192.

55. Suyama, H.; Benes, S.E.; Robinson, P.H.; Getachew, G.; Grattan, S.R.; Grieve, C.M. Biomass yield and nutritional quality of forage species under long-term irrigation with saline-sodic drainage water: Field evaluation. Anim. Feed Sci. Technol. 2007, 135, 329-345. [CrossRef]

56. Al-Shorepy, S.; Alhadrami, G.; Ayoub, M.; Dakheel, A. Growth performance and body composition of indigenous goats fed Distichlis hay. In Proceedings of the 5th Annual UAE University Research Conference, Al-Ain, UAE, 25-27 April 2004.

57. Al-Shorepy, S.; Alhadrami, G.; Dakheel, A. Effect of feeding Sporobolus grass hay on growth performance and slaughtering characteristics of fattening indigenous lambs. In Proceedings of the 6th Annual UAE University Research Conference, Al-Ain, UAE, 24-26 April 2005.

58. Alhadrami, G.; Al-Shorepy, S.; Dakheel, A. Effect of feeding long term Sporobolus grass hay on growth performance of Awassi sheep. In Proceedings of the 6th Annual UAE University Research Conference, Al-Ain, UAE, 24-26 April 2005.

59. Sarwar, M.; Mahr-un-Nisa; Ajmal Khan, M.; Mushtaque, M. Chemical composition, herbage yield and nutritive value of Panicum antidotale and Pennisetum orientale for Nili buffaloes at different clipping intervals. Asian-Australas. J. Anim. Sci. 2006, 19, 176-180. [CrossRef]

60. Norman, H.C.; Masters, D.G.; Wilmot, M.G.; Rintoul, A.J. Effect of supplementation with grain, hay or straw on the performance of weaner Merino sheep grazing old man (Atriplex nummularia) or river (Atriplex amnicola) saltbush. Grass Forage Sci. 2008, 63, 179-192. [CrossRef]

61. Masters, D.G.; Rintoul, A.J.; Dynes, R.A.; Pearce, K.L.; Norman, H.C. Feed intake and production in sheep fed diets high in sodium and potassium. Aust. J. Agric. Res. 2005, 56, 427-434. [CrossRef] 
62. Pearce, K.L.; Masters, D.G.; Jacob, R.H.; Hopkins, D.L.; Pethick, D.W. Effects of sodium chloride and betaine on hydration status of lambs at slaughter. Aust. J. Exp. Agric. 2008, 48, 1194-1200. [CrossRef]

63. Pearce, K.L.; Pethick, D.W.; Masters, D.G. The effect of ingesting a saltbush and barley ration on the carcass and eating quality of sheepmeat. Animal 2008, 2, 479-490. [CrossRef] [PubMed]

64. Masters, D.; Tiong, M.; Vercoe, P.; Norman, H. The nutritive value of river saltbush (Atriplex amnicola) when grown in different concentrations of sodium chloride irrigation solution. Small Rumin. Res. 2010, 91, 56-62. [CrossRef]

65. Masters, D.G.; Norman, H.C. 15-Genetic and Environmental Management of Halophytes for Improved Livestock Production. In Halophytes for Food Security in Dry Lands; Khan, M.A., Ozturk, M., Gul, B., Ahmed, M.Z., Eds.; Academic Press: San Diego, CA, USA, 2016; pp. 243-257, ISBN 978-0-12-801854-5.

66. Edgerton, M.D. Increasing Crop Productivity to Meet Global Needs for Feed, Food, and Fuel. Plant Physiol. 2009, 149, 7-13. [CrossRef] [PubMed]

67. Masuda, T.; Goldsmith, P.D. World soybean production: Area harvested, yield, and long-term projections. Int. Food Agribus. Manag. Rev. 2009, 12, 143-162. [CrossRef]

68. Enghiad, A.; Ufer, D.; Countryman, A.M.; Thilmany, D.D. An Overview of Global Wheat Market Fundamentals in an Era of Climate Concerns. Int. J. Agron. 2017, 2017, 1-15. [CrossRef]

69. Sukenik, A. Production of eicosapentaenoic acid by the marine eustigmatophyte Nannochloropsis. In Chemicals from Microalgae; Taylor \& Francis: London, UK, 1999; pp. 41-56, ISBN 0748405151.

70. Corder, R.E.; Hill, A.M.; Lindsey, H.; Lowenstein, M.; McIntosh, R.P. SERI Biomass Program FY, 1983 Annual Report; Solar Energy Research Institute: Golden, CO, USA, 1984.

71. Arad, A. A Development of Outdoor Raceway Capable of Yielding Oil-Rich Halotolerant Microalgae; Solar Energy Research Institute: Golden, CO, USA, 1984.

72. Slegers, P.M.; Lösing, M.B.; Wijffels, R.H.; van Straten, G.; van Boxtel, A.J.B. Scenario evaluation of open pond microalgae production. Algal Res. 2013, 2, 358-368. [CrossRef]

73. Volesky, B.; Holan, Z.R. Biosorption of heavy metals. Biotechnol. Prog. 1995, 11, 235-250. [CrossRef] [PubMed]

74. Mehta, S.K.; Gaur, J.P. Use of Algae for Removing Heavy Metal Ions From Wastewater: Progress and Prospects. Crit. Rev. Biotechnol. 2005, 25, 113-152. [CrossRef] [PubMed]

75. Dunstan, W.M.; Menzel, D.W. Continuous Cultures of Natural Populations of Phytoplankton in Dilute, Treated Sewage Effluent1. Limnol. Oceanogr. 1971, 16, 623-632. [CrossRef]

76. Becker, W. Microalgae in Human and Animal Nutrition. In Handbook of Microalgae Culture; Blackwell Science: Oxford, UK, 2004; pp. 312-351.

77. Goldberg, I. Single Cell Protein; Springer: Berlin, Germany, 1985.

78. Naylor, R.L.; Hardy, R.W.; Bureau, D.P.; Chiu, A.; Elliott, M.; Farrell, A.P.; Forster, I.; Gatlin, D.M.; Goldburg, R.J.; Hua, K.; et al. Feeding aquaculture in an era of finite resources. Proc. Natl. Acad. Sci. USA 2009, 106, 15103-15110. [CrossRef] [PubMed]

79. Saavedra, M.; Voltolina, D. The chemical composition of Chaetoceros sp. (Bacillariophyceae) under different light conditions. Comp. Biochem. Physiol. Part B Comp. Biochem. 1994, 107, 39-44. [CrossRef]

80. Muhaemin, M.; Kaswadji, R.F. Biomass Nutrient Profiles of Marine Microalgae Dunaliella salina. J. Penelit. Sains 2009, 13, 64-67.

81. Pav, M.; Garc, J.; Martorell, C.; Aroca, S. Direct spectrophotometric method to determine cell density of Isochrysis galbana in serial batch cultures from a larger scale fed-batch culture in exponential phase. NEREIS 2015, 8, 35-43.

82. Kent, M.; Welladsen, H.M.; Mangott, A.; Li, Y. Nutritional evaluation of Australian microalgae as potential human health supplements. PLoS ONE 2015, 10, e118985. [CrossRef] [PubMed]

83. Buono, S.; Colucci, A.; Angelini, A.; Langellotti, A.L.; Massa, M.; Martello, A.; Fogliano, V.; Dibenedetto, A. Productivity and biochemical composition of Tetradesmus obliquus and Phaeodactylum tricornutum: Effects of different cultivation approaches. J. Appl. Phycol. 2016, 28, 3179-3192. [CrossRef]

84. Becker, E.W. Micro algae as a source of protein. Biotechnol. Adv. 2007, 25, 207-210. [CrossRef] [PubMed]

85. Das, P.; Thaher, M.I.; Hakim, M.A.; Al-Jabri, H.M.; Alghasal, G.S. A comparative study of the growth of Tetraselmis sp. in large scale fixed depth and decreasing depth raceway ponds. Bioresour. Technol. 2016, 216, 114-120. [CrossRef] [PubMed] 
86. Das, P.; Quadir, M.A.; Chaudhary, A.K.; Thaher, M.I.; Khan, S.; Alghazal, G.; Al-Jabri, H. Outdoor continuous cultivation of self-settling marine cyanobacterium Chroococcidiopsis sp. Ind. Biotechnol. 2018, 14, 45-53. [CrossRef]

87. FAO. Available online: http://www.fao.org/wairdocs/tan/x5926e/x5926e01.htm (accessed on 24 April 2018).

88. Grieshop, C.M.; Fahey, G.C. Comparison of quality characteristics of soybeans from Brazil, China, and the United States. J. Agric. Food Chem. 2001, 49, 2669-2673. [CrossRef] [PubMed]

89. Portz, L.; Cyrino, J.E.P. Digestibility of nutrients and amino acids of different protein sources in practical diets by largemouth bass Micropterus salmoides (Lacepede, 1802). Aquac. Res. 2004, 35, 312-320. [CrossRef]

90. Tibbetts, S.M.; Bjornsson, W.J.; McGinn, P.J. Biochemical composition and amino acid profiles of Nannochloropsis granulata algal biomass before and after supercritical fluid $\mathrm{CO}_{2}$ extraction at two processing temperatures. Anim. Feed Sci. Technol. 2015, 204, 62-71. [CrossRef]

91. Benemann, J. Microalgae for Biofuels and Animal Feeds. Energies 2013, 6, 5869-5886. [CrossRef]

92. Hemaiswarya, S.; Raja, R.; Kumar, R.R.; Ganesan, V.; Anbazhagan, C. Microalgae: A sustainable feed source for aquaculture. World J. Microbiol. Biotechnol. 2011, 27, 1737-1746. [CrossRef]

93. Pereira, H.; Barreira, L.; Custódio, L.; Alrokayan, S.; Mouffouk, F.; Varela, J.; Abu-Salah, K.M.; Ben-Hamadou, R. Isolation and fatty acid profile of selected microalgae strains from the red sea for biofuel production. Energies 2013, 6, 2773-2783. [CrossRef]

94. James, C.M.; Al-Khars, A.M. An intensive continuous culture system using tubular photobioreactors for producing microalgae. Aquaculture 1990, 87, 381-393. [CrossRef]

95. James, C.M.; Al-Hinty, S.; Salman, A.E. Growth and $\omega 3$ fatty acid and amino acid composition of microalgae under different temperature regimes. Aquaculture 1989, 77, 337-351. [CrossRef]

96. Abu-rezq, T.S.; Al-hooti, S.; Jacob, D.A. Optimum culture conditions required for the locally isolated Dunaliella salina. J. Algal Biomass Util. 2010, 1, 12-19.

97. Kitto, M.R.; Reginald, M. Effect of summer/winter light intensity and salt on growth kinetics and beta carotene accumulation by Dunaliella in open outdoor earthern ponds in a desert island, off UAE coast. J. Algal Biomass Util. 2011, 2, 14-21.

98. Saadaoui, I.; Al Ghazal, G.; Bounnit, T.; Al Khulaifi, F.; Al Jabri, H.; Potts, M. Evidence of thermo and halotolerant Nannochloris isolate suitable for biodiesel production in Qatar Culture Collection of Cyanobacteria and Microalgae. Algal Res. 2016, 14, 39-47. [CrossRef]

99. Das, P.; Thaher, M.I.; Hakim, M.A.; Al-Jabri, H.M. Sustainable production of toxin free marine microalgae biomass as fish feed in large scale open system in the Qatari desert. Bioresour. Technol. 2015, 192, 97-104. [CrossRef] [PubMed]

100. Das, P.; Thaher, M.I.; Abdul Hakim, M.A.; Al-Jabri, H.M.; Alghasal, G.S. Microalgae harvesting by pH adjusted coagulation-flocculation, recycling of the coagulant and the growth media. Bioresour. Technol. 2016, 216, 824-829. [CrossRef] [PubMed]

101. Fon Sing, S.; Isdepsky, A.; Borowitzka, M.A.; Lewis, D.M. Pilot-scale continuous recycling of growth medium for the mass culture of a halotolerant Tetraselmis sp. in raceway ponds under increasing salinity: A novel protocol for commercial microalgal biomass production. Bioresour. Technol. 2014, 161, 47-54. [CrossRef] [PubMed]

102. Horiuchi, J.; Ohba, I.; Tada, K.; Kobayashi, M.; Kanno, T.; Kishimoto, M. Effective Cell Harvesting of the Halotolerant Microalga Dunaliella tertiolecta with pH Control. J. Biosci. Bioeng. 2003, 95, 412-415. [CrossRef]

103. Rogers, J.N.; Rosenberg, J.N.; Guzman, B.J.; Oh, V.H.; Mimbela, L.E.; Ghassemi, A.; Betenbaugh, M.J.; Oyler, G.A.; Donohue, M.D. A critical analysis of paddlewheel-driven raceway ponds for algal biofuel production at commercial scales. Algal Res. 2014, 4, 76-88. [CrossRef]

104. Rashid, N.; Rehman, S.U.; Han, J.-I. Rapid harvesting of freshwater microalgae using chitosan. Process Biochem. 2013, 48, 1107-1110. [CrossRef]

105. Ndikubwimana, T.; Zeng, X.; He, N.; Xiao, Z.; Xie, Y.; Chang, J.S.; Lin, L.; Lu, Y. Microalgae biomass harvesting by bioflocculation-interpretation by classical DLVO theory. Biochem. Eng. J. 2015, 101, 160-167. [CrossRef]

106. Choy, S.Y.; Prasad, K.M.N.; Wu, T.Y.; Raghunandan, M.E.; Phang, S.-M.; Juan, J.C.; Ramanan, R.N. Separation of Chlorella biomass from culture medium by flocculation with rice starch. Algal Res. 2018, 30, 162-172. [CrossRef] 
107. Knuckey, R.M.; Brown, M.R.; Robert, R.; Frampton, D.M.F. Production of microalgal concentrates by flocculation and their assessment as aquaculture feeds. Aquac. Eng. 2006, 35, 300-313. [CrossRef]

108. Rwehumbiza, V.M.; Harrison, R.; Thomsen, L. Alum-induced flocculation of preconcentrated Nannochloropsis salina: Residual aluminium in the biomass, FAMEs and its effects on microalgae growth upon media recycling. Chem. Eng. J. 2012, 200-202, 168-175. [CrossRef]

109. Salim, S.; Bosma, R.; Vermuë, M.H.; Wijffels, R.H. Harvesting of microalgae by bio-flocculation. J. Appl. Phycol. 2010, 23, 849-855. [CrossRef] [PubMed]

110. Talukder, M.M.R.; Das, P.; Wu, J.C. Immobilization of microalgae on exogenous fungal mycelium: A promising separation method to harvest both marine and freshwater microalgae. Biochem. Eng. J. 2014, 91, 53-57. [CrossRef]

111. Worm, B.; Barbier, E.B.; Beaumont, N.; Duffy, J.E.; Folke, C.; Halpern, B.S.; Jackson, J.B.C.; Lotze, H.K.; Micheli, F.; Palumbi, S.R.; et al. Impacts of biodiversity loss on ocean ecosystem services. Science 2006, 314, 787-790. [CrossRef] [PubMed]

112. MOAF Considering 24 Aquaculture Projects Worth RO 853 Million. 20 May 2017. Available online: http:/ / www.muscatdaily.com/Archive/Oman/MoAF-considering-24-aquaculture-projects-worthRO853mn-50x1 (accessed on 24 April 2018).

113. Ataullah, S. Plan to Set up Floating Fish Farms in Sea. The Penninsula, 13 February 2017. Available online: https:/ / www.thepeninsulaqatar.com/article/13/02/2017/Plan-to-set-up-floating-fish-farms-in-sea (accessed on 24 April 2018).

114. Xiao, X.; Agusti, S.; Lin, F.; Li, K.; Pan, Y.; Yu, Y.; Zheng, Y.; Wu, J.; Duarte, C.M. Nutrient removal from Chinese coastal waters by large-scale seaweed aquaculture. Sci. Rep. 2017, 7, 46613. [CrossRef] [PubMed]

115. Goldman, J. So You Want to Be a Fish Farmer. Available online: https://umaine.edu/cooperativeaquaculture/wp-content/uploads/sites/75/2015/11/So-You-Want-to-be-a-Fish-Farmer-by-JoshGoldman.pdf (accessed on 17 April 2018).

116. Warshay, B.; Brown, J.J.; Sgouridis, S. Erratum to: Life cycle assessment of integrated seawater agriculture in the Arabian (Persian) Gulf as a potential food and aviation biofuel resource. Int. J. Life Cycle Assess. 2017, 22, 1033. [CrossRef]

117. Bailis, R.; Yu, E. Environmental and social implications of integrated seawater agriculture systems producing Salicornia bigelovii for biofuel. Biofuels 2012, 3, 555-574. [CrossRef]

118. Alkhamisi, S.A.; Ahmed, M. Opportunities and Challenges of Using Treated Wastewater in Agriculture. In Environmental Cost and Face of Agriculture in the Gulf Cooperation Council Countries: Fostering Agriculture in the Context of Climate Change; Shahid, S.A., Ahmed, M., Eds.; Springer International Publishing: Cham, Switzerland, 2014; pp. 109-123, ISBN 978-3-319-05768-2.

119. Shahid, S.A.; Al-Shankiti, A. Sustainable food production in marginal lands-Case of GDLA member countries. Int. Soil Water Conserv. Res. 2013, 1, 24-38. [CrossRef]

120. Siddiqi, A.; Anadon, L.D. The water-energy nexus in Middle East and North Africa. Energy Policy 2011, 39, 4529-4540. [CrossRef]

121. Al Iriani, M.A.; Trabelsi, M. The economic impact of phasing out energy consumption subsidies in GCC countries. J. Econ. Bus. 2016, 87, 35-49. [CrossRef]

122. Meltzer, J.; Hultman, N.E.; Langley, C. Low-carbon energy transitions in Qatar and the Gulf cooperation council region. In Brookings Pap. Econ. Act.; Brookings Institution: Washington, DC, USA, 2014.

123. Elmi, A.A. Food Security in the Arab Gulf Cooperation Council States. In Sustainable Agriculture Reviews; Lichtfouse, E., Ed.; Springer International Publishing: Cham, Switzerland, 2017; pp. 89-114, ISBN 978-3-319-58679-3.

124. Sewilam, H.; Nasr, P. Desalinated Water for Food Production in the Arab Region. In The Water, Energy, and Food Security Nexus in the Arab Region; Amer, K., Adeel, Z., Böer, B., Saleh, W., Eds.; Springer International Publishing: Cham, Switzerland, 2017; pp. 59-81, ISBN 978-3-319-48408-2.

(C) 2018 by the authors. Licensee MDPI, Basel, Switzerland. This article is an open access article distributed under the terms and conditions of the Creative Commons Attribution (CC BY) license (http:/ / creativecommons.org/licenses/by/4.0/). 